\title{
TRACE METAL POLLUTION OF RECENT MOLLUSCAN SHELLS FROM LAKE QARUN SEDIMENTS, EGYPT
}

\author{
Ibrahim M. Lofty \\ Institute of Oceano. \& Fish.,Egypt.
}

Key words: environmental factors, trace metals, mollusc shells, Lake Qarun.

\begin{abstract}
This paper aims to present a complete picture on the trace metals I distribution in the recent mollusk an shells from Lake Qarun sediments. The mollusk an shells were collected during August 2003 and analyzed for the trace metals viz: $\mathrm{As}, \mathrm{Ba}, \mathrm{Cd}, \mathrm{Cr}, \mathrm{Co}, \mathrm{Cu}, \mathrm{Fe}, \mathrm{Mn}$. $\mathrm{Mo}, \mathrm{Ni}$, $\mathrm{Pb}, \mathrm{Se}, \mathrm{Sr}, \mathrm{V}$ and $\mathrm{Zn}$. Their relative order abundance in bivalve shells was: $\mathrm{Fe}>\mathrm{Cu}>\mathrm{Sr}>\mathrm{Zn}>\mathrm{Mn}>\mathrm{Pb}>\mathrm{Ni}>\mathrm{Se}>\mathrm{As}>\mathrm{Ba}>\mathrm{Cr}>\mathrm{Mo}>\mathrm{Co}>\mathrm{V}>\mathrm{Cd}$, while in gastropod shells was: : $\mathrm{Fe}>\mathrm{Zn}>\mathrm{Mn}>\mathrm{Sr}>\mathrm{Cu}>\mathrm{As}>\mathrm{Pb}>\mathrm{Se}>$ $\mathrm{Ba}>\mathrm{Ni}>\mathrm{Cr}>\mathrm{Mo}>\mathrm{Co}>\mathrm{V}>\mathrm{Cd}$. The elements were more abundant in gastropod shells. Most elements were associated with aragonite( i.e. nepionic stage) in eastern and middle zone close to the source of the elements and with increasing age (i.e. in adult stage) associated with calcite in western sector. This is due to the mineralogy of shells, secondary alteration, location, environmental parameters, activity of organisms and source of sediments.
\end{abstract}

\section{INTRODUCTION}

Lake Qarun (Fig. 1) is located in an arid region occupying the deepest part of Fayoum depression in the western desert of Egypt. The lake is a closed, complex ecosystem has dynamic sediments. Closed, because it is an inland saline basin of about $4 \mathrm{~km}$ length, $5.7 \mathrm{~km}$ width, and has an average depth $4.2 \mathrm{~m}$. Complex, because several state variables are needed to describe it, because the lake is not a homogeneous system but its various parts have different characteristics, and dynamic sedimet... because the physical, chemical and biological characteristics vary continuously over time. The lake may be regarded as a reactor limited sideward, upwards and downwards by three interfaces( human activity, 
agriculture drains/ water, water/ air and water/sediments ) at which the exchanges of material are particularly active.

Due to the low average depth of the lake, the productive layer is in direct contact with activities of the decomposers and are most active. This accelerates the biogeochemical cycle between the macro- and micro fauna, sediments and the water. Pollution of lake systems is in an inevitable consequence of urban, rural and industrial development. Pollutants types and sources are diverse and include phosphorus and nitrogen from rural and agricultural practices, trace metals derived from industrial sources including base metal refining and metallurgical processing (Wittman, 1981; Roy and Crawford, 1984; Batley, 1987; Chenhall et. al., 1993) and sediment influx in excess of natural levels (Kilby and Balty, 1993).

Throughout of world, one key adverse environmental impact of trace metal contamination of the sediment and water column, not only in lake, but also in terrestrial, riverine and marine settings. This is the potential for transference of toxic metals ( e.g. $\mathrm{Pb}, \mathrm{As}, \mathrm{Cd}, \mathrm{Hg}$ ) into the food chain (Wittman, 1981; Keller, 1992; Lalibert et. Al., 1992). Geochemical study of recent mollusk shells was recently dealt in details by several authors as Lowenstam ( 1954 ), Turikian and Armstrong, 1960, Pilky and Goodel ( 1962 ), Dodd ( 1963 ), Chave( 1964 ), Aliev ( 1971), Clark and Lutz ( 1980 ), Ismail and Abdel Aal ( 1986 ) and lotfy (1997, 2000, 2001, 2002 and 2003 ).

In such dynamic ecosystem and in view of the increased role of agriculture drain water reaching the lake, important changes have taken place which need to be evaluated and documented.

For this reason, the present study is deemed to be necessary. It includes detailed study on the status of fifteen elements in surficial molluscan shells in sediments to illustrate the relation between chemical composition, mineralogy, metabolism, secondary alteration and ecologic interpretation.

\section{MATERIAL AND METHODS}

Lake bottom samples (25 stations) were collected once during August 2003, using Peterson grab sampler (Fig. 1).

Lake water samples were collected at each station (Fig. 1) for determination of dissolved oxygen and salinity that analyzed according to the methods described by Strickland and Parsons (1972) and Packman induction salinometer. The $\mathrm{pH}$ values of water were measured by a pocket 
$\mathrm{pH}$ meter directly in the field. The total alkalinity was determined by titration versus standard $\mathrm{HCl}$, using methyl orange indicator.

The shells of the bivalve Haminoeo orbgnyana ( nepionic and adult) and the gastropod Melanoides tuberculata (nepionic and adult) were separated from the samples and identified.

The concentrations of $\mathrm{As}, \mathrm{Ba}, \mathrm{Cr}, \mathrm{Co}, \mathrm{Cu}, \mathrm{Fe}, \mathrm{Mn}$. Mo, $\mathrm{Ni}, \mathrm{Pb}, \mathrm{Se}$, $\mathrm{Sr}, \mathrm{V}, \mathrm{Zn}$ in the studied species were determined using the Inductivity Coupled Plasms (ICP) in the Central Laboratory for Environmental Quality Monitoring (CLEQM), National Water Research Center, Kanater, Egypt.

The $\mathrm{pH}$ values of sediments were determined by a pocket $\mathrm{pH}$ meter in the laboratory. The chloride content of sediments was measured gravimetrically according to the method mentioned by Hillebrand et al. (1953). Carbonate was determined by the method described by Alexeyev (1971) and organic matter was determined according to the method of El Wakeel and Riley (1957).

\section{RESULTS AND DISCUSSION}

\section{General Characteristics of Lake Water and Sediments}

According to the data recorded in Table (1) and Fig. (2), the dissolved oxygen in the west zone was $8.72 \mathrm{mg} / \mathrm{l}$, then it decreased towards the middle zone $(7.46 \mathrm{mg} / \mathrm{l})$ and attained lowest eastwards $(6.2$ $\mathrm{mg} / \mathrm{l}$ ). Changes in total alkalinity content in water attained a highest value westwards $(94.3 \mathrm{mg} / \mathrm{l})$, then decreased towards the middle and eastwards reached to $78.32 \mathrm{mg} / \mathrm{l}$ and $62.32 \mathrm{mg} / \mathrm{l}$, respectively.

Values of salinity in bottom water at the study site was $33.21 \%$ in average, ranging from $38.68 \%$ at highest in west zone to and $27.64 \%$ at lowest in east zone and $33.16 \%$ at middle zone. The $\mathrm{pH}$ value of water was 8.9 in average, ranging from 8.6 at lowest in east zone to 9.2 at highest in west zone and 8.9 in middle zone.

Lake Qarun sediments showed a wide variation in carbonate content from one place to another. The calculated average of carbonate content was varied from $29.77 \%$ at east zone to $37.42 \%$ at west zone and attained $36.63 \%$ at the middle zone. The average of total salt content ranged between $0.25 \%$ at the middle, $0.3 \%$ and $0.36 \%$ at highest in east and west zone, respectively. The distribution of organic matter in the bottom sediments of the lake follows the salt content distribution. The highest was observed at west zone and attained $18.6 \%$, while in the middle and east zones reached to $12.6 \%$ and $16.4 \%$, respectively. The $\mathrm{pH}$ 
values of sediment were 9.2 in average, ranging between 9.11 at lowest in east sector and 9.31 at highest in middle zone, and it reaçhed to 9.25 at west zone.

Lotfy (1997) proved that the carbonate phases of mollusk shells (i.e. Haminoeo orbgnyana) consist mainly of aragonite and calcite (Table 1 and Fig. 2). The maximum value of aragonite was occurred in the eastern area $(97.88 \%$ ), and decreased westwards $992.5 \%$ ), while calcite content reached to The maximum value (7.5\%) at west area, and $2.12 \%$ at lowest in east zone. He also proved that the carbonate phases of gastropod shells (i.e. Melanoides tuberculata) consist mainly of aragonite and calcite. Aragonite content was varied between $28.5 \%$ at west area and $93.5 \%$ at east zone, while calcite content ranged from $6.5 \%$ at east zone to $71.5 \%$ at west zone.

\section{Trace Elements Abundance in Bivalve Shells}

Trace metals abundances in bivalve shells from Lake Qarun sediments have been previously documented by Lotfy. (1997), who concluded that the most abundant trace elements of environmental significance were $\mathrm{Mg}, \mathrm{Sr}, \mathrm{Fe}$ and $\mathrm{Mn}$. The levels of $\mathrm{Mg}, \mathrm{Fe}$ and $\mathrm{Mn}$ increased generally westwards, where the $\mathrm{Sr}$ level decreased in that direction.

Tables (2, 3 and 4) and Figs. (3, 4 and 5), show the levels of arsenic (As), barium (Ba), cadmium (Cd), chromium ( $\mathrm{Cr}$ ), cobalt (Co), copper $(\mathrm{Cu})$, iron (Fe), manganese $(\mathrm{Mn})$, molybdenium (Mo), nickel (Ni), lead $(\mathrm{Pb})$, selenium (Se), strontium (Sr); vanadium $(\mathrm{V})$ and zinc $(\mathrm{Zn})$ in the studied bivalve shells (i.e. Haminoeo orbgnyana in nepionic and adult stage) and gastropod shells (i.e. Melanoides tuberculata in nepionic and adult) from the sediments of Lake Qarun.

From Table (2) and Fig. (3); the average level of $\mathrm{As}$ and $\mathrm{Ba}$ in bivalve shells ranged between $0.12-0.68$ and $0.21-0.63 \mathrm{ppm} \times 10^{-3}$, respectively. The As in adult stage of Haminoeo orbgnyana attained a highest value in west zone with an average of $2.1 \mathrm{ppm} \times 10^{-3}$, then it decreased abruptly in the middle zone with an average of $0.12 \mathrm{ppm} \times 10^{-3}$, while a highest value of $\mathrm{Ba}$ was recorded westwards, $\left(0.63 \mathrm{ppm} \times 10^{-3}\right)$ and the lowest towards the middle zone $\left(0.16 \mathrm{ppm} \times 10^{-3}\right)$, As level in nepionic stage ranged between $0.13-0.68 \mathrm{ppm} \times 10^{-3}$ and the maximum value in the middle zone, while Ba level varied from $0.25-0.33 \mathrm{ppm} \times 10^{-3}$, and attained a highest value in west zone. Generally, the highest value of As was recorded in the middle zone and nepionic stage, while $\mathrm{Ba}$ increased westwards and in adult stage. 
The average levels of $\mathrm{Cd}, \mathrm{Co}, \mathrm{Cr}, \mathrm{Cu}$ and $\mathrm{Fe}$ varied between 0.003 $0.11,0.01-0.5,0.012-0.7,0.14-6.8,0.8-6.7 \mathrm{ppm} \times 10^{-3}$, respectively. According to the distribution of these elements in Haminoeo orbgnyana, the eastern zone proved to have a high $\mathrm{Fe}$ level, reaching $6.7 \mathrm{ppm} \times 10^{-3}$ in adult stage, while the high value of $\mathrm{Cu}\left(6.8 \mathrm{ppm} \times 10^{-3}\right)$ was recorded in the middle zone and nepionic stage. Finally, the western zone proved to have a high levels of $\mathrm{Cd}, \mathrm{Co}$ and $\mathrm{Cr}$ in adult stage, reaching to $0.11,0.5$ and $0.7 \mathrm{ppm} \times 10^{-3}$,respectively.

From Table( 2) and Fig. (3), the levels of $\mathrm{Mn}, \mathrm{Mo}, \mathrm{Ni}$, and $\mathrm{Pb}$ in the Haminoeo orbgnyana shells ranged from 0.5-2.2, 0.01- 0.5, 0.009- 5.4 and $0.1-5.4 \mathrm{ppm} \times 10^{-3}$, respectively. Their maximum values were recorded westwards and in adult stage, except $\mathrm{Mn}$ in nepionic stage .

The mean level values of $\mathrm{Se}, \mathrm{Sr}, \mathrm{V}$ and $\mathrm{Zn}$ varied between $0.09-2.5$, $0.6-5.2,0.007-0.14$ and $0.95-2.63 \mathrm{ppm} \times 10^{-3}$, respectively. Their distribution attained the highest in western sector in adult stage, except $\mathrm{Sr}$ and $\mathrm{Zn}$ in nepionic stage.

The zonal distribution of trace metals in bivalve shells of Lake Qarun proved that the highest level of $\mathrm{Ba}, \mathrm{Cd}, \mathrm{Co}, \mathrm{Cr}, \mathrm{Mn}, \mathrm{Mo}, \mathrm{Ni}, \mathrm{Pb}, \mathrm{Se}, \mathrm{Sr}, \mathrm{V}$ and $\mathrm{Zn}$ was found in western sector, while $A s$ and $\mathrm{Cu}$ values increased in middle zone and $F e$ reached the highest in eastern zone.

According to the age of the shells, the highest levels of $\mathrm{Ba}, \mathrm{Cd}, \mathrm{Co}$, $\mathrm{Cr}, \mathrm{Fe}, \mathrm{Mo}, \mathrm{Ni}, \mathrm{Pb}, \mathrm{Se}, \mathrm{Sr}$ and $\mathrm{V}$ attained in adult stage, while that of $\mathrm{As}$, $\mathrm{Cu}, \mathrm{Mn}, \mathrm{Sr}$, and $\mathrm{Zn}$ were recorded in nepionic stage.

Enrichment Factors(E.F.)for the shells can be derived using the following expression:

\begin{tabular}{|c|c|}
\hline E.F. & mean concentration of trace metals in nepionic stage \\
\hline
\end{tabular}

With the exception of the eastern sector( close to the El Bats agriculture drain), the E.F. for $\mathrm{As}, \mathrm{Cd}, \mathrm{Cu}$, and $\mathrm{Sr}$ were greater than $1.55,2.33,1.29$, and 1.44 , respectively, while $\mathrm{Ba}, \mathrm{Co}, \mathrm{Cr}, \mathrm{Fe}, \mathrm{Mn}, \mathrm{Mo}, \mathrm{Ni}$, $\mathrm{Pb}, \mathrm{Se}, \mathrm{V}$ and $\mathrm{Zn}$ levels exhibited low enrichment in nepionic stage.

In the middle sector( close to the El-Wadi agriculture drains), the E.F. for $\mathrm{As}, \mathrm{Ba}, \mathrm{Cd}, \mathrm{Co}, \mathrm{Cr}, \mathrm{Cu}, \mathrm{Fe}, \mathrm{Mo}, \mathrm{Ni}, \mathrm{Pb}, \mathrm{Se}, \mathrm{V}$ and $\mathrm{Zn}$ were greater than $5.67,1.56,1.8,9.2,6,48.58,189,12,7.78,5,8,8.57$ and 2.66 , respectively, while $\mathrm{Mn}$ and $\mathrm{Sr}$ levels exhibited low enrichment in nepionic stage.

In the west sector, the $\mathrm{E}, \mathrm{F}$, for $\mathrm{Mn}, \mathrm{Sr}$ and $\mathrm{Zn}$ were greater than 1.57, 1.86 and 1.56 , respectively, while $\mathrm{As}, \mathrm{Ba}, \mathrm{Cd}, \mathrm{Co}, \mathrm{Cr}, \mathrm{Cu}, \mathrm{Fe}, \mathrm{Mo}, \mathrm{Ni}, \mathrm{Pb}$, $\mathrm{Se}$ and $\mathrm{V}$ levels in nepionic stage exhibited low enrichment. 


\section{Trace Elements Abundance in Gastropod Shells}

Lotfy (2000) concluded that $\mathrm{Fe}, \mathrm{Mn}$ and $\mathrm{Zn}$ are more associated with bivalve shells, while $\mathrm{Cu}, \mathrm{Pb}$ and $\mathrm{Cd}$ are more associated with gastropod shells. From Table( 3 )and Fig. (4), the mean concentration of $\mathrm{As}, \mathrm{Ba}, \mathrm{Cd}$, $\mathrm{Co}$ and $\mathrm{Cr}$ in gastropod shells( i.e. Melanoides tuberculata) varied between $0.3-5.3,0.06-2.7,0.001-2.7,0.01-1$ and $0.01-0.56 \mathrm{ppm} \times 10^{-3}$, respectively. According to the zonal distribution of these trace metals in gastropod shells, the western sector proved to have the high values of As, $\mathrm{Ba}, \mathrm{Cd}$ and $\mathrm{Co}$ levels, reaching 5.3, 2.7, 0.07 and $1 \mathrm{ppm} \times 10^{-3}$, respectively, in adult stage, while $\mathrm{Cr}$ level increased in middle zone and in nepionic stage.

The average levels of $\mathrm{Cu}, \mathrm{Fe}, \mathrm{Mn}, \mathrm{Mo}$ and $\mathrm{Ni}$ in the Melanoides tuberculata shells were 0.13-4.1, 0.9- 5.4, 0.9- 5.9, 0.02- 0.7 and 0.1$1.04 \mathrm{ppm} \times 10^{-3}$, respectively. The distribution of $\mathrm{Cu}$ and $\mathrm{Fe}$ in gastropod shells were reached to the maximum value in nepionic stage and western sector, while the high value of $\mathrm{Mn}, \mathrm{Mo}$ and $\mathrm{Ni}$ were recorded in adult stage and western sector.

The mean concentrations of $\mathrm{Pb}, \mathrm{Se}, \mathrm{Sr}, \mathrm{V}$ and $\mathrm{Zn}$ in gastropod shells are shown in Table (3) and Fig. (4). Their average levels were 0.09-4.4, $0.13-2.6,0.12-6.9,0.007-0.4$ and $0.54-7.64 \mathrm{ppm} \times 10^{-3}$ respectively. According the zonal distribution of $\mathrm{Pb}, \mathrm{Se}, \mathrm{Sr}, \mathrm{V}$ and $\mathrm{Zn}$ in gastropod shells, the western zone proved to have the maximum values in adult stage. Finally, in the distribution of trace metals in gastropod shells, the highest levels of $\mathrm{As}, \mathrm{Ba}, \mathrm{Cd}, \mathrm{Co}, \mathrm{Cu}, \mathrm{Fe}, \mathrm{Mn}, \mathrm{Mo}, \mathrm{Ni}, \mathrm{Pb}, \mathrm{Se}, \mathrm{Sr}, \mathrm{V}$ and $\mathrm{Zn}$ were found in western sector, while $\mathrm{Cr}$ level was increased in the middle zone.

According to the age of Melanoides tuberculata snails, the highest levels of $\mathrm{As}, \mathrm{Ba}, \mathrm{Cd}, \mathrm{Co}, \mathrm{Mn}, \mathrm{Mo}, \mathrm{Ni}, \mathrm{Pb}, \mathrm{Se}, \mathrm{Sr}, \mathrm{V}$ and $\mathrm{Zn}$ attained in the adult stage, while the highest levels of $\mathrm{Cr}, \mathrm{Cu}$ and $\mathrm{Fe}$ appeared in nepionic stage.

With the exception of the western sector, the E.F. for $\mathrm{Cu}$ and $\mathrm{Fe}$ were greater than 2.28 and 1.38 , while $\mathrm{As}, \mathrm{Ba}, \mathrm{Cd}, \mathrm{Co}, \mathrm{Cr}, \mathrm{Mn}, \mathrm{Mo}, \mathrm{Ni}, \mathrm{Pb}$, $\mathrm{Se}, \mathrm{Sr}, \mathrm{V}$ and $\mathrm{Zn}$ levels in nepionic stage exhibited low enrichment factors (Table 4).

In the middle sector( close to the El-Wadi agriculture drains), the E.F. for $\mathrm{As}, \mathrm{Cd}, \mathrm{Co}, \mathrm{Cr}, \mathrm{Cu}, \mathrm{Fe}$ and $\mathrm{Zn}$ were greater than $1,1,8,2,67$, $5.49,3.31$ and 3.73, respectively, while $\mathrm{Ba}, \mathrm{Mn}, \mathrm{Mo}, \mathrm{Ni}, \mathrm{Pb}, \mathrm{Se}, \mathrm{Sr}$ and $\mathrm{V}$ in nepionic shells had the lowest enrichment factors. 
In the eastern sector( close to the El Bats agriculture drain), the E.F. for $\mathrm{Ba}, \mathrm{Cd}, \mathrm{Co}, \mathrm{Cr}, \mathrm{Cu}, \mathrm{Fe}, \mathrm{Mn}, \mathrm{Mo}, \mathrm{Ni}, \mathrm{Pb}, \mathrm{Se}, \mathrm{Sr}, \mathrm{V}$ and $\mathrm{Zn}$ were gregter than $3.33,10,2.5,2,2,0.08,3.11,2.78,3,4,3.33,3.85,1.2,9.33 .4 .29$ and 6.96 , respectively. While As value in nepionic stage exhibited low enrichment factors.

\section{Trace Metals Distribution and Environmental Factors}

Zonal trace metals distribution and environmental factors changes proved that the west sector of the lake is characterized by elevated average values of $\mathrm{Ba}, \mathrm{Cd}, \mathrm{Co}, \mathrm{Cr}, \mathrm{Mo}, \mathrm{Ni}, \mathrm{Pb}, \mathrm{Se}, \mathrm{V}$ and $\mathrm{Zn}$ in adult stage while $\mathrm{Mn}, \mathrm{Fe}$ and $\mathrm{Se}$ in nepionic stage. In gastropod shells $\mathrm{As}, \mathrm{Ba}, \mathrm{Cd}$, $\mathrm{Co}, \mathrm{Mn}, \mathrm{Mo}, \mathrm{Ni}, \mathrm{Pb}, \mathrm{Se}, \mathrm{Sr}, \mathrm{V}$ and $\mathrm{Zn}$ levels are high in acult stage, while the middle zone is enriched in $\mathrm{As}$ and $\mathrm{Cu}$ in nepionic of bivalve shells, while in gastropod shells is enriched with $\mathrm{Cr}$ in nepionic shells. Finally in eastern zone, the lake is enriched with $\mathrm{Fe}$ in adult stage in bivalve shells.

The relative order of abundance of elements in bivalve shells is: $\mathrm{Fe}>\mathrm{Cu}>\mathrm{Sr}>\mathrm{Zn}>\mathrm{Mn}>\mathrm{Pb}>\mathrm{Ni}>\mathrm{Se}>\mathrm{As}>\mathrm{V}>\mathrm{Ba}>\mathrm{Cr}>\mathrm{Mo}>\mathrm{Co}>\mathrm{Cd}$. While in gastropod is: $\mathrm{Fe}>\mathrm{Zn}>\mathrm{Mn}>\mathrm{Sr}>\mathrm{Cu}>\mathrm{As}>\mathrm{Pb}>\mathrm{Se}>\mathrm{Ba}>\mathrm{Ni}>\mathrm{Cr}>$ $\mathrm{Mo}>\mathrm{Co}>\mathrm{V}>\mathrm{Cd}$.

$\mathrm{Cd}, \mathrm{Cu}, \mathrm{Fe}, \mathrm{Ni}$ and $\mathrm{V}$ are more abundant in bivalve, while As, $\mathrm{Ba}$, $\mathrm{Co}, \mathrm{Cr}, \mathrm{Mn}, \mathrm{Mo}, \mathrm{Pb}, \mathrm{Se}, \mathrm{Sr}$, and $\mathrm{Zn}$ are more abundant in gastropod shells.

By using the E. F. relations, it is proved that in the eastern zone (close to El-Bats drain) $\mathrm{Ba}, \mathrm{Co}, \mathrm{Cr}, \mathrm{Fe}, \mathrm{Mn}, \mathrm{Mo}, \mathrm{Ni}, \mathrm{Pb}, \mathrm{Se}, \mathrm{Sr}, \mathrm{V}$ and $\mathrm{Zn}$ levels exhibited high enrichment in the bivalve nepionic shells, while As, $\mathrm{Cd}, \mathrm{Cu}$ and $\mathrm{Sr}$ were low $\mathrm{Ba}, \mathrm{Cd}, \mathrm{Co}, \mathrm{Cr}, \mathrm{Cu}, \mathrm{Fe}, \mathrm{Mn}, \mathrm{Mo}, \mathrm{Ni}, \mathrm{Pb}, \mathrm{Se}, \mathrm{Sr}$, $\mathrm{V}$ and $\mathrm{Zn}$ were greater in nepionic stage, while As in adult stage.

In the middle zone (close to El-Wadi drain), most of elements were high abundant in nepionic bivalve shells, except $\mathrm{Mn}$ and $\mathrm{Sr}$. While in gastropod shells $\mathrm{As}, \mathrm{Cd}, \mathrm{Co}, \mathrm{Cu}, \mathrm{Fe}$ and $\mathrm{Zn}$ were more abundant in nepionic stage.

In western sector, most of elements have maximum value in nepionic bivalve shells, except $\mathrm{Mn}, \mathrm{Sr}$ and $\mathrm{Zn}$ were low. In gastropods, most of elements were more enrichment in adult stage, except $\mathrm{Cu}$ and $\mathrm{Fe}$ were more abundant in nepionic stage.

The relationship matrix between trace metals distribution and the environmental factors (Figs 2, 3, 4 and 5) shows the following: the combined values have strong pathetic and antipathetic relations. Chlorite, organic matter, carbonate, calcite and some chemical parameters in water ( salinity, $\mathrm{pH}$, alkalinity and oxygen), most of elements in bivalve (except 
$\mathrm{As}, \mathrm{Cu}$ and $\mathrm{Fe}$ ) and most of elements in gastropod shells (except $\mathrm{Cr}$ ) are positively correlated with each other and increase westwards. In middle zone, As is reached to high value in bivalve shells and $\mathrm{Cr}$ in gastropod shells. In eastern zone which has a high content of aragonite, there is decreasing in environmental parameters and increasing in $\mathrm{Fe}$ in bivalve shells.

Thus, as expected most of elements are incorporated into carbonate phases (Lotfy, 1997, 2000, 2002 and 2003; Kostka et al. 1999, Vital, 1999; Labonne et al., 2003).

There are several factors, of which the most important are temperature, salinity, water depth and siliclastic, that control carbonate minerals deposition as $\mathrm{BaCO}_{3}$ (witherite), $\mathrm{FeCO}_{3}$ (siderite), $\mathrm{PbCO}_{3}$ (cerussite), $\mathrm{MnCO}_{3} \quad$ (rhodochrosite), $\quad \mathrm{SrCO}_{3}$ (stronianite), $\mathrm{ZnCO}_{3}$ (smithsonite) and others Keiler, 1992).

The organic matter in sediments is known to be slightly enriched in many of the rarer elements, particularly $\mathrm{V}, \mathrm{Mo}, \mathrm{Ni}, \mathrm{Co}, \mathrm{As}$ and $\mathrm{Cu}$, and locally many others (Henderson, 1984).

Matching the average levels of elements in mollusk shells of Lake Qarun (Tables 2 and 3) with those in carbonate sediments (Turikian et al. 1961), results indicated that $\mathrm{Cr}$ and $\mathrm{Pb}$ are slightly enriched in the mollusk shells. With comparison with standard shale ( Krauskopf and Bird, 1995), results showed that most elements are low except $\mathrm{Cd}, \mathrm{Cu}$ and Se in mollusk shells.

The remobilization of elements from sources is mainly controlled by the absorbed processes and is mostly caused by four types of chemical changes in water: 1)elevated salt, 2). changes in the redox, 3)lowering of $\mathrm{pH}$ and 4) increasing alkalinity, in addition to biochemical processes and activity of organisms.

However, in the mollusc shells of Lake Qarun which consist mainly of aragonite mineral, by variation of environmental factors in sediments (increasing of chloride, organic matter and carbonate and decreasing of $\mathrm{pH}$ values) and in water (increasing of salinity, $\mathrm{pH}$, alkalinity and oxygen content) and by variation of aragonite to calcite, there in ten dency to high accumulation of $\mathrm{Ba}, \mathrm{Cd}, \mathrm{Co}, \mathrm{Cr}, \mathrm{Mn}, \mathrm{Mo}, \mathrm{Ni}, \mathrm{Pb}, \mathrm{Se}, \mathrm{Sr}, \mathrm{V}$ and $\mathrm{Zn}$ in Luvalve shells and most of elements in gastropod shells by depending on thic activity of organisms.

The results proved that the main sources of trace metals in the mollusc shells in lake Qarun is the agricultural drains as El-Bats and EIWadi, due to the high association of trace metals in the nepionic stage of 
mollusc shells at the region close to the drains (i.e. eastern and middle zones), and with increasing distance and time, trace metals concentrate in the adult stage (westwards).

\section{CONCLUSIONS}

The distribution of fifteen of trace metals ( $\mathrm{As}, \mathrm{Ba}, \mathrm{Cd}, \mathrm{Cr}, \mathrm{Co}, \mathrm{Cu}$, $\mathrm{Fe}, \mathrm{Mn}$. Mo, $\mathrm{Ni}, \mathrm{Pb}, \mathrm{Se}, \mathrm{Sr}, \mathrm{V}$ and $\mathrm{Zn}$ ) in recent mollusk an shells, that were collected from Lake Qarun sediments, proved that western zone is characterizes by elevated average values of $\mathrm{Ba}, \mathrm{Cd}, \mathrm{Cr}, \mathrm{Co}, \mathrm{Mo}, \mathrm{Ni}, \mathrm{Pb}$, $\mathrm{Se}, \mathrm{V}$ and $\mathrm{Zn}$ in bivalve adult stage and $\mathrm{Mn}$ and $\mathrm{Sr}$ in nepionic stage, while $\mathrm{As}$ and $\mathrm{Cu}$ were highly enrichment in middle sector in nepionic bivalve shells and $\mathrm{Fe}$ is highly enrichment in eastern zone in adult bivalve shells. In gastropod shells $\mathrm{As}, \mathrm{Ba}, \mathrm{Cd}, \mathrm{Co}, \mathrm{Mn}$. $\mathrm{Mo}, \mathrm{Ni}, \mathrm{Pb}, \mathrm{Se}, \mathrm{Sr}, \mathrm{V}$ and $\mathrm{Zn}$ were highly enrichment in western sector in adult stage, while $\mathrm{Cu}$ and Fe were highly enrichment in eastern zone in nepionic stage.

Their total average levels in mollusc shells were: $1.04,0.58,0.02$, $0.24,0.17,2.4,3.52,2,0.19,0.7,1.26,0.9,2.3,0.08$ and 2.49 , respectively.

The relative order abundance of elements in bivalve shells is: $\mathrm{Fe}>$ $\mathrm{Cu}>\mathrm{Sr}>\mathrm{Zn}>\mathrm{Mn}>\mathrm{Pb}>\mathrm{Ni}>\mathrm{Se}>\mathrm{As}>\mathrm{V}>\mathrm{Ba}>\mathrm{Cr}>\mathrm{Mo}>\mathrm{Co}>\mathrm{Cd}$, in gastropod shells is: $\mathrm{Fe}>\mathrm{Zn}>\mathrm{Mn}>\mathrm{Sr}>\mathrm{Cu}>\mathrm{As}>\mathrm{Pb}>\mathrm{Se}>\mathrm{Ba}>\mathrm{Ni}>\mathrm{Cr}>$ $\mathrm{Mo}>\mathrm{Co}>\mathrm{V}>\mathrm{Cd}$.

The most elements are more abundant in gastropod shelis. By using of E.F., the distribution of elements proved that most of elements are more associated in nepionic stage in eastern and middle sectors which are close to agriculture drains and mineral composition of shells (i.e. more aragonite), tends to increase towards the western zone in adult stage of molluscan shells.

The distribution of trace metals in the mollusk shells is mainly controlled by some factors as elevated salt, increasing organic matter, $\mathrm{pH}$, alkalinity and oxygen content and decreasing of $\mathrm{pH}$ in sediments and transformation of aragonite to calcite, tend to increase absorbed processes of trace metals in the carbonate phases westwards.

All elements in molluscan shells were lower than that of standard shale and carbonate sediments, except $\mathrm{Cd}, \mathrm{Cu}$ and $\mathrm{Se}$, which are shown higher levels when compared with those recorded in the carbonate sediments. 


\section{REFERENCES}

Wittman, G.T.W., eds. Metal Pollution in Aquatic Environment, Springer Verlag, Berlin: 3- 68. Alexeyev V.(1971). Quantitative analysis. Mir. Publ. Moscow, 563pp.

Aliev, C.A. (1971). Paleoecological and biogeochemical investigations of molluscan shells from east Azerbiadjan. Ph. D. Thesis, Bako Univer., Soviet Union.

Batley, G.E. (1987). Heavy metal speciation in waters, sediments and biota from lake Macquarie, New South Wales. Austr. J. OF Mari. \& Freshwater Res., 38: 591- 606.

Chave, K.E.( 1964). Skeletal durability and preservation (Approaches paleoecology). Jon Willey and Sons. Inc.New York, Sydney.

Chenhall, B.E.; Yassini, I. and Jones, B.G. (1992).Heavy metal concentrations in lagoonal saltmarsh species, Illawarra region, southeastem Australia. The Science of the Total Environment, 125: 203-225.

Clark, C.R. and Lutz, R.A.(1980). Pyritization in the shells of living bivalves, Geology, 8:268- 271 .

Dodd; J.R. (1963). Environmentally controlled $\mathrm{Sr}$ and $\mathrm{Mg}$ variation in Mytilus. Geo. Soc. Progr. Ann. Mecting Astract Geo. Soc. Amre. Spe. Papers: 76-96.

EL Wakeel, S.K. and Rily, J.P.(1961). Chemical and mineralogical studies of deep sea sediments. Geochem. Acta, 25:110- 146.

Forstner, V. and Wittman, G.T.W. (1981). Metal pollution in the aquatic environment. Springer Verlag. Berlin: 486pp.

Henderson, P. (1984). Rare earth element. A series of papers on rare earth distribution, especially good on application of rare earth data to petrogenetic problems, Elsevier, New York. 
Hillebrand, W.F. (1953). Applied Inorganic Analysis. John Willeya Sons, N.Y.

Ismail, M.M. and Abd El Aal, A.A. (1986). A geochemical study of middle and upper Eocene bivalve shells from the Helwan area, Egypt. N.J.Geo.Paleo., M. H., 8: 867- 474.

Keller, E.A. (1992). Environmental Geology. MacMillan Publ. Comp., N.Y.

Kilby G.W. and Batly G.E.(1993). Chemical indicators of sediment chronology. Austr. J. of Mari. \& Freshwater Res., 44:635- 647.

Kostka, J.E., Haefele, E.; Viehweger, R. and Stucki, J.W. (1999): Respiration and dissolution on iron(III) contaning clay minerals by bacteria. J. Envir. Sci. and Tech., 33 (18). 3127-3133.

Krauskopf, K.B. and Bird, D.K. (1995). Introduction to geochemistry. Mc Graw-Hill, Inc. New York, $3^{\text {rd }}$ ed., 647pp.

Labonne, M.; Rousseau, D.P.; Ben Othman, D. and Lack, J. (2003). ${ }^{87} \mathrm{Sr} /{ }^{86} \mathrm{Sr}$ ratios and $\mathrm{R}^{\mathrm{EE}}$ concentrations from substratum and land snail shells, from Eustis Loess sequence (Nebraska, USA): Abridge between biological and geochemical data. Quaternary Res., Soumis.

Laliberte, C.; Dewailly, E.; Gugras, S.; Ayotte, P.; Weber, J.P.; Sauve, L. and Benedette, J.L. (1992). Mercury contamination in fishermen of thr lower north shore of the Gulf of St. Lawrence (Quebec Canada). In: Vernet J.P. ed. Impact of Heavy Metals in the Environment, Elesvier, Amesterdam, 15: 15- 28.

Lotfy, I.M.H. (1997). Mineralogical and geochemical studies of some recent molluscan shells from lake Qarun sediments, Egypt. Delta J. Sci., 21(1):50- 73.

Lotfy, I.M.H. (2000). Mineralogical and geochemical study on recent mollusk shells from lake Manzalah sediments, Egypt. Delta J. Sci., 24: 87- 104. 
Lotfy, I.M.H. (2002). Mineralogical studies and trace metals in four recent molluscan shells from Rosetta Nile branch sediments, Egypt. Bull. Nat. Inst. of Oceanogr. \& Fish., ARE , 28: 349366.

Lotfy, I.M.H. (2003). Mineralogical and geochemical studies on four recent molluscan shells from Hypersalline Bardawil lagoon sediments, Egypt. J. Egypt Acad. Soc. Environ. Develop., 4(2): 199-218.

Lowensiam, H.A. (1954). Factors affecting the aragonite/calcite ratios in carbonate secreting marine organisms. J. Geol., 62: 287-317.

Pilkey, O.H. and Goodel, H.G. (1962). Evolution of the use of $\mathrm{Sr}$ as a paleoecologic tool. Geol. Soc. Am. Spec. papers, 68: 78- 79.

Roy, P.S. and Crawford, E.A. (1984). Heavy metals in a contaminated Australian estusry- dispersion and accumulation trend. Estuarine, Coastal and shelf Sci., 19: 341- 358.

Strickland, J.D.H. and Parsons, T.R. (1972). A practical handbook of sea water analysis. Fish. Res. Bl. Canada, 167, $2^{\text {nd }}$ ea.: 310.

Turikian, K.K. and Armstrong, K.L. (1960). $\mathrm{Mg}, \mathrm{Sr}$ and $\mathrm{Ba}$ concentrations and calcite, aragonite ratios of some molluscan shells. J. Marine Res., 18: 133.

Turikian, K.K. and Wedepohl, K.H. (1961). Distribution of the element in some majors units of the Earths crust. Geol. Soc. Am. Bull., 72: 175- 192.

Vital, H.; Stategger, R. and Garbeschonberg, C.D. (1999). Composition and trace element geochemistry of detritus clay and heavy mineral suites of the lower most Amzon river. J. Sed.Res., 69 (3A): 563- 575 .

Wittman, G.T.W. (1981). Toxic metals. In: Forestner U. and Wittman G.T.W. EDS. Metal pollution in the aquatic environment. , Springler- Verlag, Berlin,pp3- 68. 


\section{TRACE METAL POLLUTION OF RECENT MOLLUSCAN 129 SHELLS FROM LAKE QARUN SEDIMENTS, EGYPT}

Table (1): The recorded average measurements of some mineralogical and chemical environmental parameters in water and sediments of Lake Qarun.( August 2003)

\begin{tabular}{|c|c|c|c|c|c|c|c|c|c|c|c|c|}
\hline Zone & \multicolumn{8}{|c|}{$\therefore \quad:$ sediment } & \multicolumn{4}{|c|}{ water } \\
\hline & $\mathrm{pH}$ & $\mathrm{Cl}^{-1}$ & O.M & $\mathrm{CO}_{3}{ }^{\circ}$ & Arag & ite\% & & te\% & $\mathrm{pH}$ & Alknl. & Salini. & $\mathrm{O}_{2}$ \\
\hline East & 9.1 & 0.3 & 16.4 & 29.8 & 97.9 & 93.5 & 2.1 & 6.5 & 8.6 & 62.3 & 27,6 & 6.2 \\
\hline Middle & 9.31 & 0.25 & 12.6 & 36.6 & 94.5 & 61 & 5.5 & 39 & 8.9 & 78.3 & 33.2 & 7.5 \\
\hline West & 9.25 & .36 & 18.6 & 37.4 & 92.5 & 28.5 & 7.5 & 71.5 & 9.2 & 94.3 & 38.7 & 8.7 \\
\hline
\end{tabular}

Table(2): Average concentration of trace metals $\left(\mathrm{ppm} \times 10^{-3}\right)$ in the bivalve shells of Haminoea Orbgnyana( $A=$ adult, $B=$ nepionic).

\begin{tabular}{|c|c|c|c|c|c|c|c|c|c|c|c|c|c|c|c|c|}
\hline zonte & 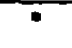 & As & $\mathrm{Ba}$ & $\mathrm{Cd}$ & Co & $\mathrm{Cr}$ & $\mathrm{Cu}$ & $\mathrm{Fe}$ & $\mathrm{Mn}$ & Mo & $\mathrm{Ni}$ & $\mathrm{Pb}$ & $\mathrm{Sc}$ & $\mathrm{Sr}$ & $\mathrm{V}$ & $2 n$ \\
\hline \multirow[t]{3}{*}{ East } & A & .20 & .32 & .003 & .09 & .23 & 2.8 & 6.7 & 1.4 & .19 & .09 & .8 & .9 & 1.1 & .09 & 1.8 \\
\hline & B & .31 & .28 & .007 & .06 & .11 & 3.6 & 4.6 & .5 & .11 & .08 & .6 & .35 & 1.5 & .03 & 1.2 \\
\hline & Ave & .26 & .3 & .005 & .08 & .17 & 3.2 & 5.6 & .98 & .15 & .08 & .7 & .55 & 1.3 & .06 & 1.6 \\
\hline \multirow[t]{3}{*}{ Mtid. } & A & .12 & .16 & .005 & .01 & .01 & .14 & 3.1 & 1.5 & .01 & .01 & .1 & .1 & 1.5 & .01 & .95 \\
\hline & $\bar{B}$ & .68 & .25 & .009 & .09 & .07 & 6.8 & 5.7 & 1.1 & .12 & .07 & .5 & .8 & .6 & .06 & 2.5 \\
\hline & Ave & .4 & .21 & .007 & .05 & .04 & 3.8 & 4.4 & 1.3 & .07 & .04 & .3 & .4 & .9 & .04 & 1.7 \\
\hline \multirow[t]{3}{*}{ west } & A & 2.1 & .63 & .41 & .7 & .7 & 3.1 & 3.7 & 1.4 & .5 & 5.4 & 5.4 & 2.5 & 2.8 & -14 & 1.7 \\
\hline & $\bar{B}$ & .13 & 33 & .007 & .1 & .1 & .59 & .8 & 2.2 & .01 & .1 & .1 & .09 & 5.2 & .01 & 2.6 \\
\hline & $\begin{array}{l}\text { Ave } \\
\text { Tot. }\end{array}$ & $\begin{array}{l}1.12 \\
.59\end{array}$ & $\begin{array}{l}.48 \\
.33\end{array}$ & $\begin{array}{c}.059 \\
.02\end{array}$ & $\begin{array}{r}.4 \\
.13\end{array}$ & $\begin{array}{l}.4 \\
.2\end{array}$ & $\begin{array}{l}1.7 \\
2.9\end{array}$ & $\begin{array}{l}2.4 \\
3.8\end{array}$ & $\begin{array}{l}1.8 \\
1.4\end{array}$ & $\begin{array}{l}.26 \\
.16\end{array}$ & $\begin{array}{l}2.7 \\
.96\end{array}$ & $\begin{array}{l}2.7 \\
1.3\end{array}$ & $\begin{array}{l}1.3 \\
.75\end{array}$ & $\begin{array}{c}4 \\
2.1\end{array}$ & $\begin{array}{l}.07 \\
.05\end{array}$ & $\begin{array}{l}2.2 \\
1.9\end{array}$ \\
\hline 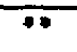 & & & 10 & - & .1 & 11 & 4 & - & 110 & .4 & 20 & 9 & .1 & 610 & 20 & 20 \\
\hline$\infty$ & & 130 & 580 & .3 & 19 & 90 & 45 & 47200 & 850 & 2.6 & 68 & 20 & .4 & 300 & 130 & 95 \\
\hline
\end{tabular}


Table(3): Average concentration of trace metals $\left(\mathrm{ppm} \times 10^{-3}\right)$ in the gastropod shells of Melanoides tuberculata $(\mathrm{C}=$ adult, $\mathrm{D}=$ nepionic $)$.

\begin{tabular}{|c|c|c|c|c|c|c|c|c|c|c|c|c|c|c|c|c|}
\hline zone & $*$ & AS & $\mathrm{Ba}$ & $\mathrm{Cd}$. & $\mathrm{Co}$ & $\mathrm{Cr}$ & $\mathrm{Cu}$ & $\mathrm{Fe}$ & $\overline{\mathrm{Mn}}$ & Mo & $\overline{N i}$ & $\mathrm{~Pb}$ & $\mathrm{Se}$ & $\mathrm{Sr}$ & $\mathrm{V}$ & $2 n$ \\
\hline \multirow[t]{3}{*}{ East } & $\bar{C}$ & .6 & .06 & .001 & .02 & .01 & .13 & .9 & .9 & .02 & .01 & .09 & .13 & .12 & .01 & .54 \\
\hline & $\bar{D}$ & 3 & .2 & .01 & .05 & .02 & .4 & 2.8 & 2.5 & .06 & .04 & .3 & .5 & 1.12 & .03 & 3.8 \\
\hline & Ave & .45 & .13 & .005 & .04 & .02 & .27 & 1.85 & 1.7 & .04 & .03 & 2 & .32 & .62 & .02 & 22 \\
\hline \multirow{3}{*}{ Mid. } & C & .8 & 1.2 & .01 & .01 & .21 & .71 & 1.6 & 2.6 & .33 & .7 & 1.6 & 1.1 & 3.11 & .11 & .88 \\
\hline & $\bar{D}$ & 8 & .36 & .01 & .08 & .56 & 3.9 & 5.3 & 1.18 & .09 & .05 & 5 & .8 & .6 & .03 & 33 \\
\hline & Ave & .8 & .78 & .01 & .04 & .39 & 2.31 & 3.45 & 1.89 & .21 & .38 & 1.1 & .95 & 1.86 & .07 & 2.1 \\
\hline \multirow[t]{4}{*}{ west } & C & 5.3 & 2.7 & .07 & 1 & .54 & 1.8 & 3.9 & 5.9 & .7 & 1.04 & 4.4 & 2.6 & 6.9 & .4 & 7.6 \\
\hline & $\bar{D}$ & 1.1 & .4 & .02 & .01 & 31 & 4.1 & 5.4 & 3.1 & .12 & .9 & .8 & 1.3 & 3.6 & .07 & 2.6 \\
\hline & Ave & 3.2 & 1.55 & .045 & .51 & .43 & 2.95 & 4.65 & 4.5 & $.4 \mathrm{k}$ & .97 & 2.6 & 1.95 & 3.6 & .24 & 5.1 \\
\hline & Tot. & .48 & .82 & .02 & .2 & .28 & 1.84 & 3.32 & 2.7 & .22 & 46 & 1.28 & 1.07 & 2.58 & .11 & 3.1 \\
\hline $4 *$ & & & 10 & - & .1 & 11 & 4 & - & 110 & .4 & 20 & 9 & .1 & 610 & 20 & 20 \\
\hline $6 \pi$ & & 130 & 580 & .3 & 19 & 90 & 45 & 47200 & 850 & 2.6 & 68 & 20 & .4 & 300 & 130 & 95 \\
\hline
\end{tabular}

Table(4): Enrichment factors of trace metals in nepionic / adult stage of A-bivalve and B-gastropod in the studied shells.

\begin{tabular}{|c|c|c|c|c|c|c|c|c|c|c|c|c|c|c|c|c|}
\hline zone & $\cdot$ & AS & $\mathrm{Ba}$ & $\mathrm{Cd}$ & $\mathrm{Co}_{0}$ & $\mathrm{Cr}$ & $\mathrm{Cu}$ & $\mathrm{Fe}$ & $\mathrm{Mn}$ & Mo & Ni & $\mathrm{Pb}$ & $\mathrm{Se}$ & $\mathrm{Sr}$ & $\bar{V}$ & $\mathrm{Zn}$ \\
\hline \multirow[t]{2}{*}{ East } & $A$ & 1.55 & $\overline{\mathrm{BB}}$ & 2.33 & .67 & .48 & 1.29 & .69 & .36 & .58 & .89 & .75 & .39 & 1.44 & .33 & .66 \\
\hline & B & .5 & 3.33 & 10 & 2.5 & 2 & 3.08 & 3.11 & 2.78 & 3 & 4 & 3.33 & 3.85 & 9.33 & 4.29 & 6.96 \\
\hline \multirow[t]{2}{*}{ Mid. } & A & 5.67 & 1.56 & 1.8 & 9.2 & 6 & 48.5 & 1.89 & .69 & $\sqrt{12}$ & 7.78 & 5 & 8 & .4 & 8.57 & 2.66 \\
\hline & B & 1 & .3 & $T$ & 8 & 2.67 & 5.49 & 3.31 & .45 & .27 & .07 & .31 & .73 & .19 & .27 & 3.73 \\
\hline west & $\mathrm{A}$ & .06 & .51 & .06 & .02 & .14 & .06 & .22 & 1.57 & .02 & .02 & .02 & .04 & 1.86 & .06 & 1.56 \\
\hline \multicolumn{2}{|c|}{$\bar{B}$} & .21 & .15 & .29 & .01 & .57 & 2.28 & 1.38 & .53 & .17 & .87 & .18 & .5 & .52 & .18 & .34 \\
\hline
\end{tabular}




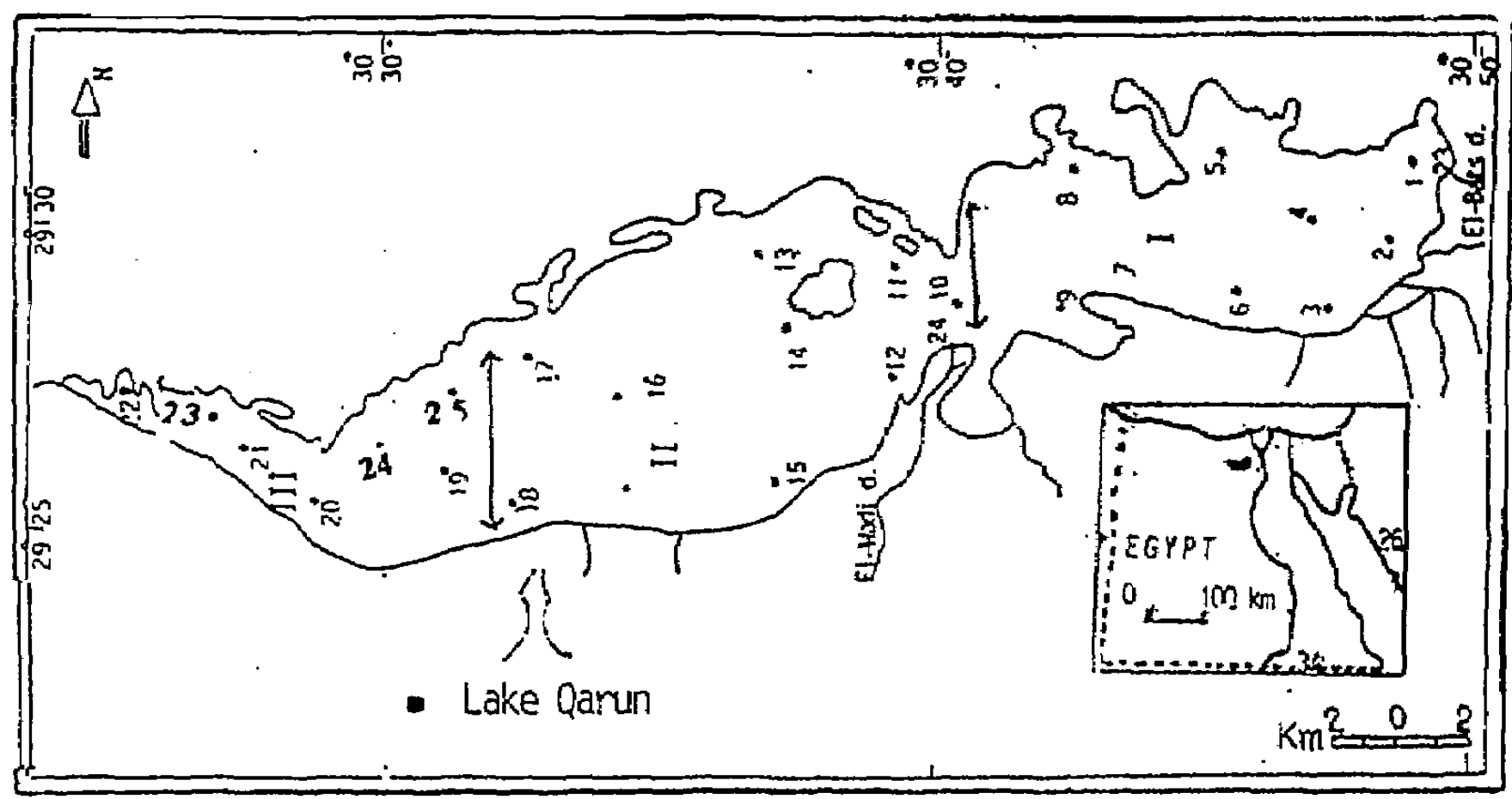

Fig (I) : Map of Lake Qarun showing the location of sampling . 
Figure(2): The zonal distribution of environmental parameters in A-Haminoea orbgnyana(bivalve) and B-Melanoides tubarculata(gastropod), sediments and water (calcite and aragonite in shells, chloride, carbonate and organic matter in sediments)
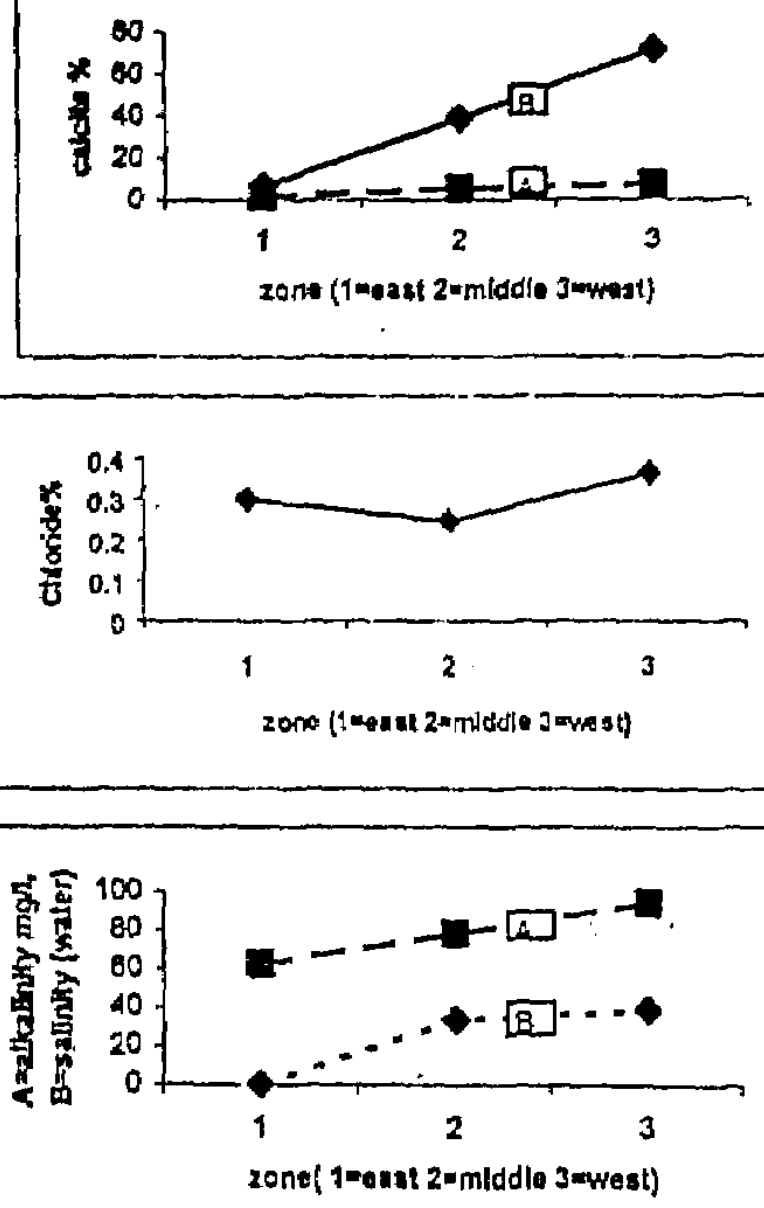
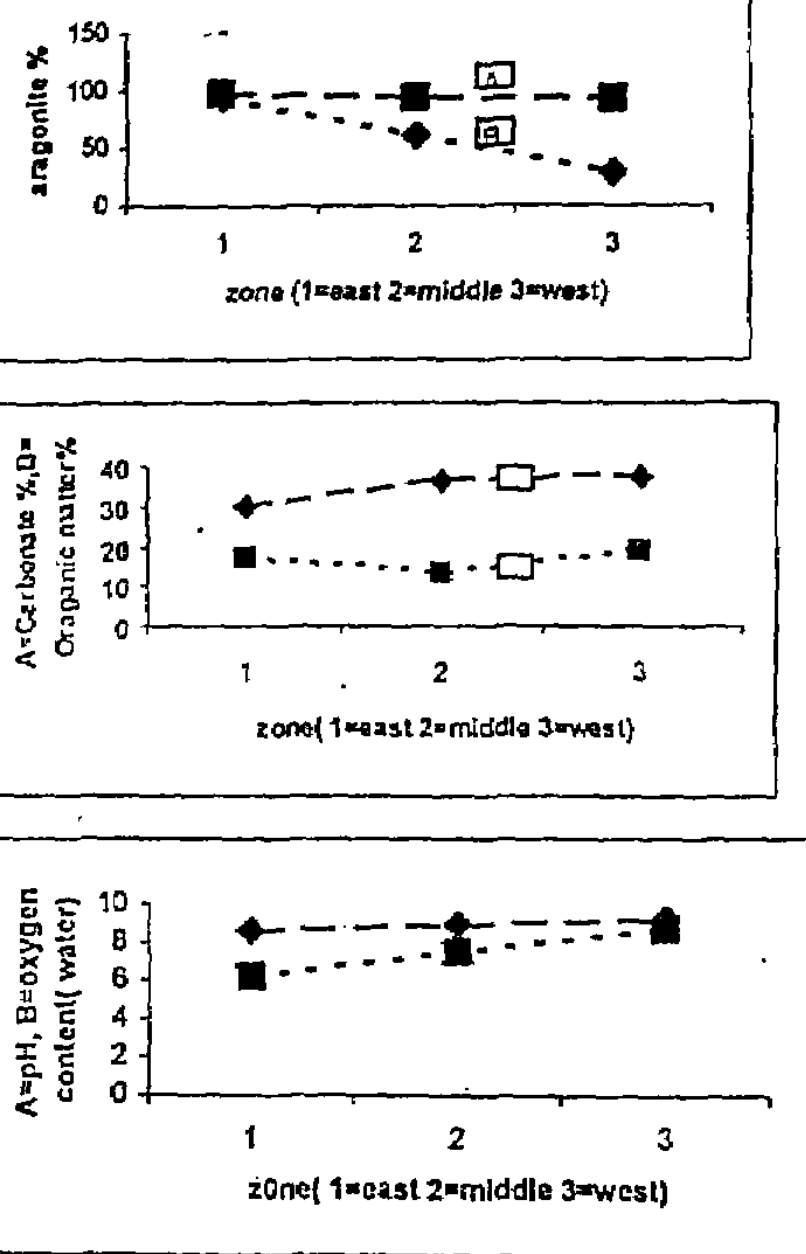

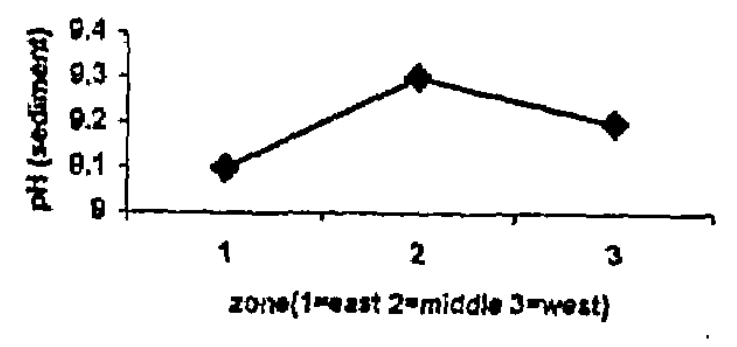




\section{TRACE METAL POLLUTION OF RECENT MOLLUSCAN 133 SHELLS FROM LAKE QARUN SEDIMENTS, EGYPT}

Figure(3): Zonal average distribution of trace metals( $\left.\mathrm{ppm} \times 10^{-3}\right)$ in the studied shells of Haminoea orbgnyana in Lake Qarun (bivalve $\mathrm{A}=$ adult, $\mathrm{B}=$ nepionic).
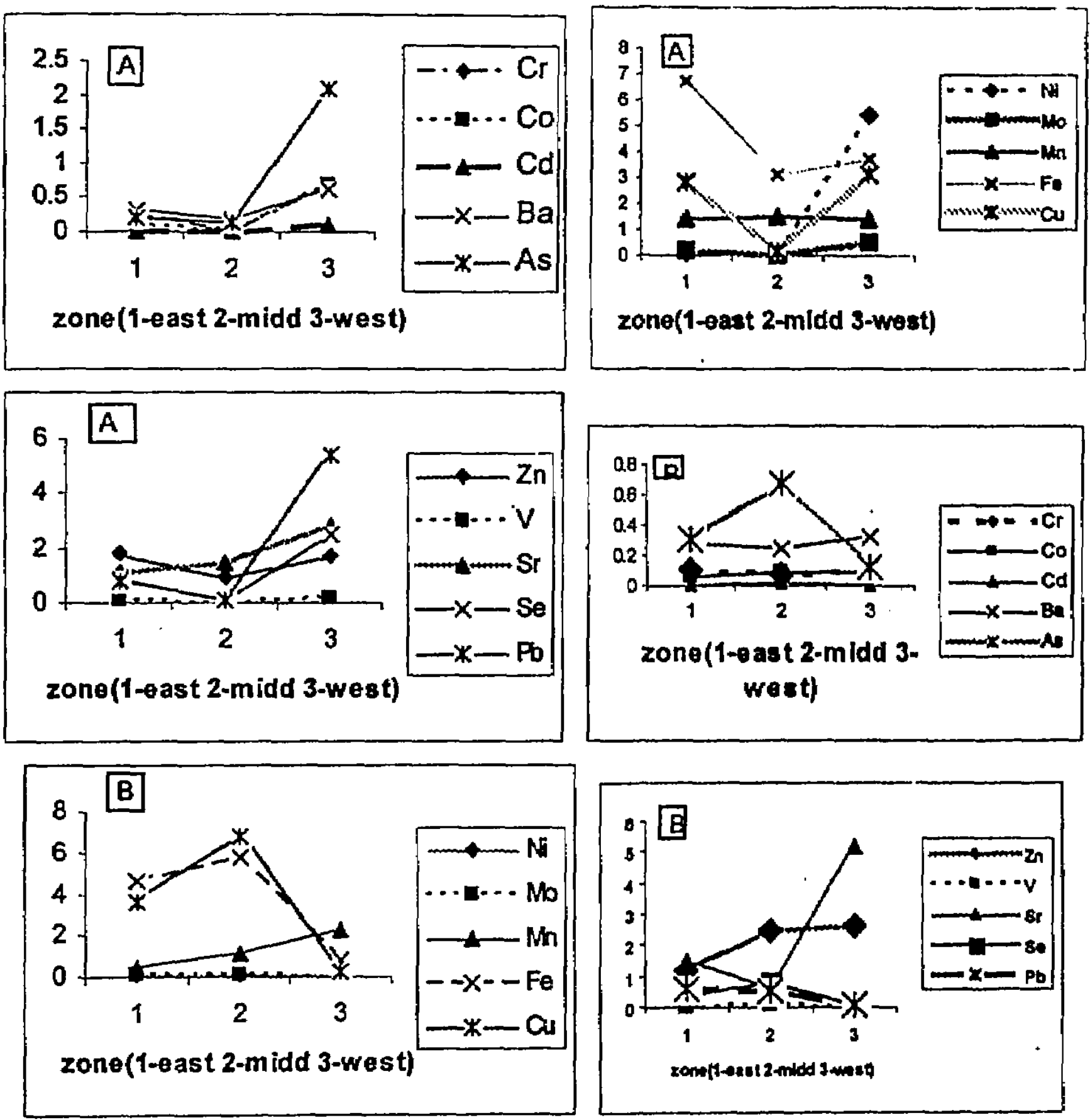
Figure(4): Zonal average distribution of trace metals(. ppm $\left.\times 10^{-3}\right)$ in the studied shells of Melanoides tuberculata in Lake Qarun (gastropod $\mathrm{C}=$ adult, $\mathrm{D}=$ nepionic).
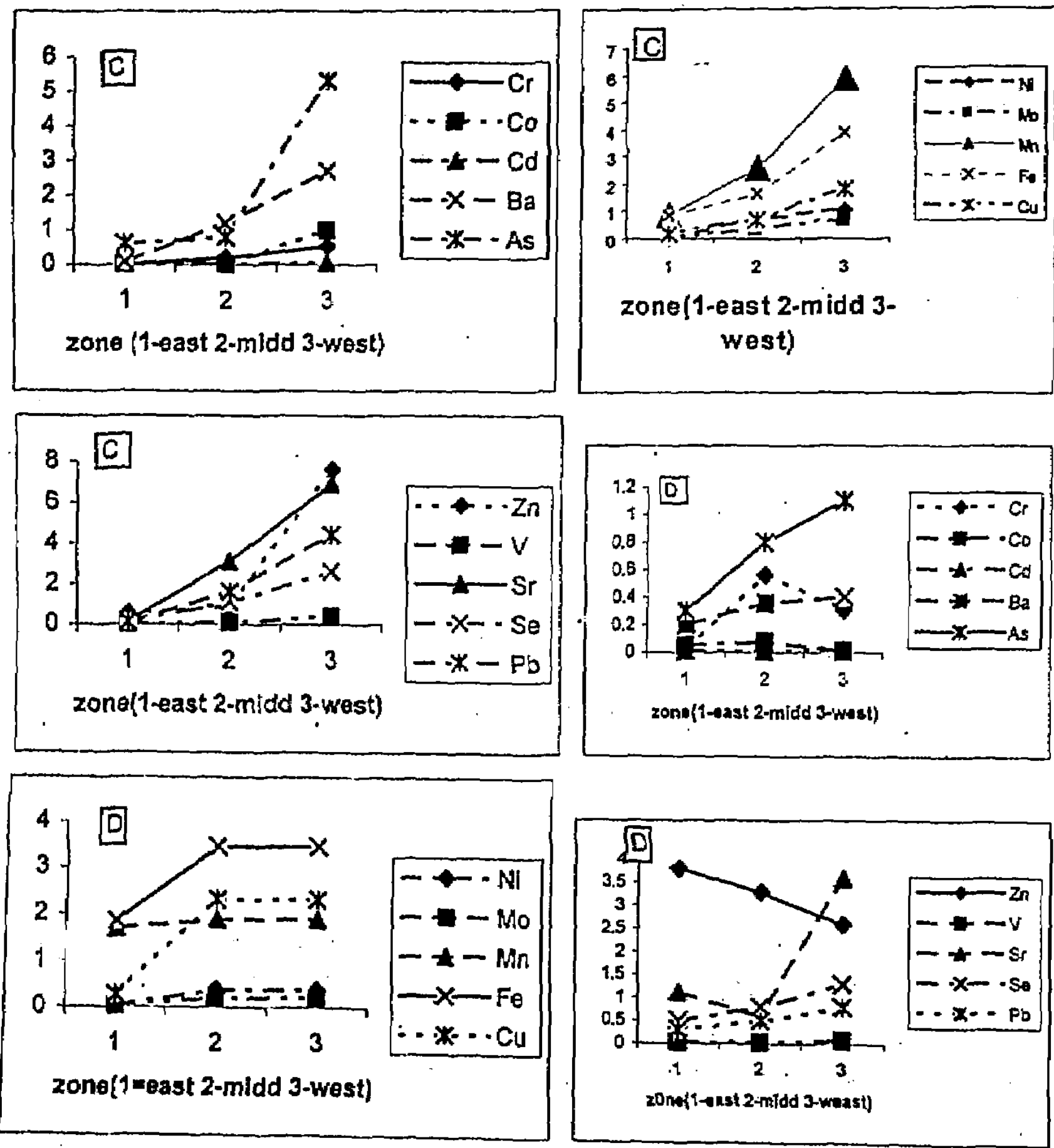


\section{TRACE METAL POLLUTION OF RECENT MOLLUSCAN 135 SHELLS FROM LAKE QARUN SEDIMENTS, EGYPT}

Figure(5): Zonal average distribution of trace metals $\left(\mathrm{ppm} \times 10^{-3}\right.$ ) in the studied shells of bivalve and gastropod from Lake Qarun.
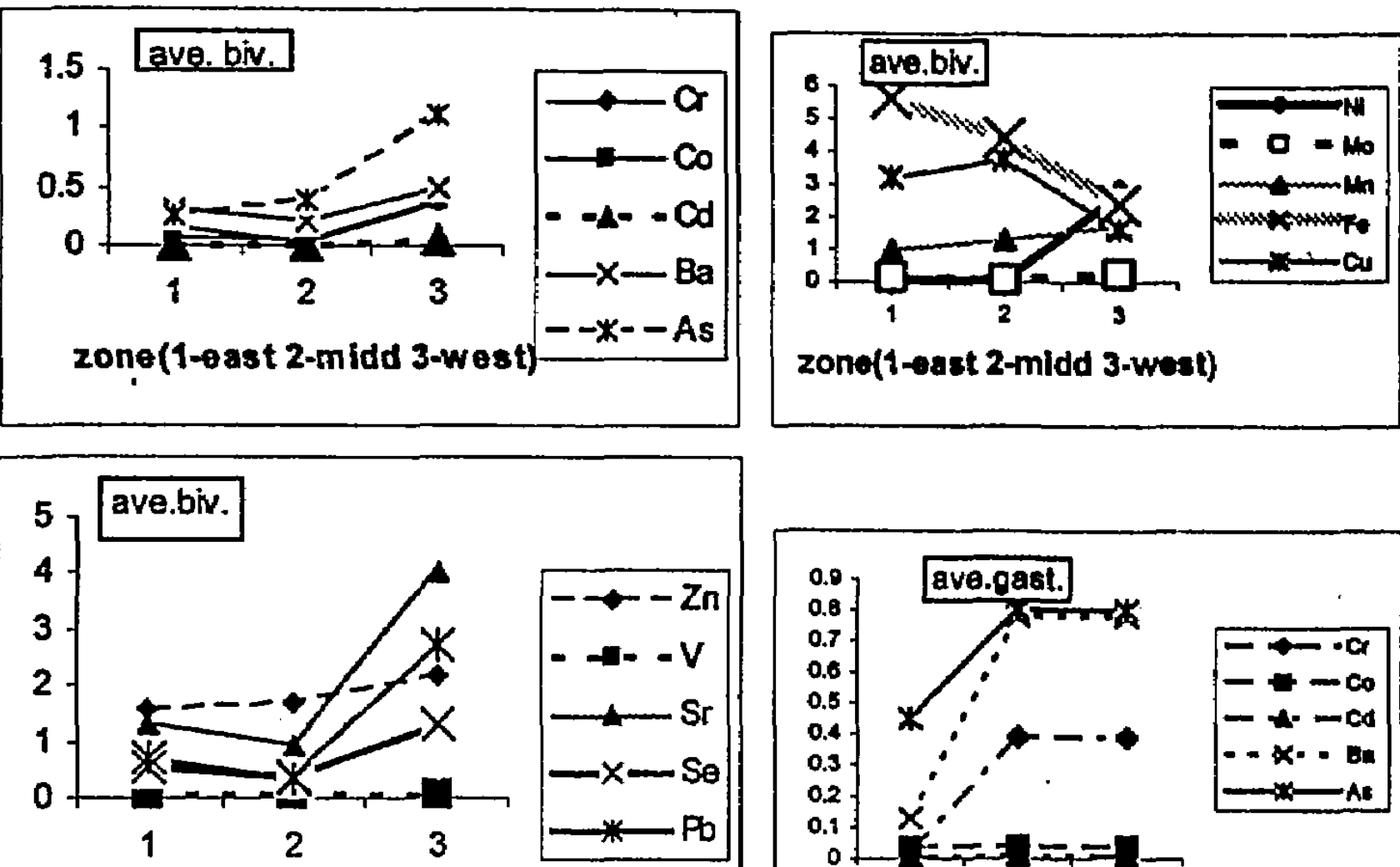

zone(1-east 2-midd 3-west)
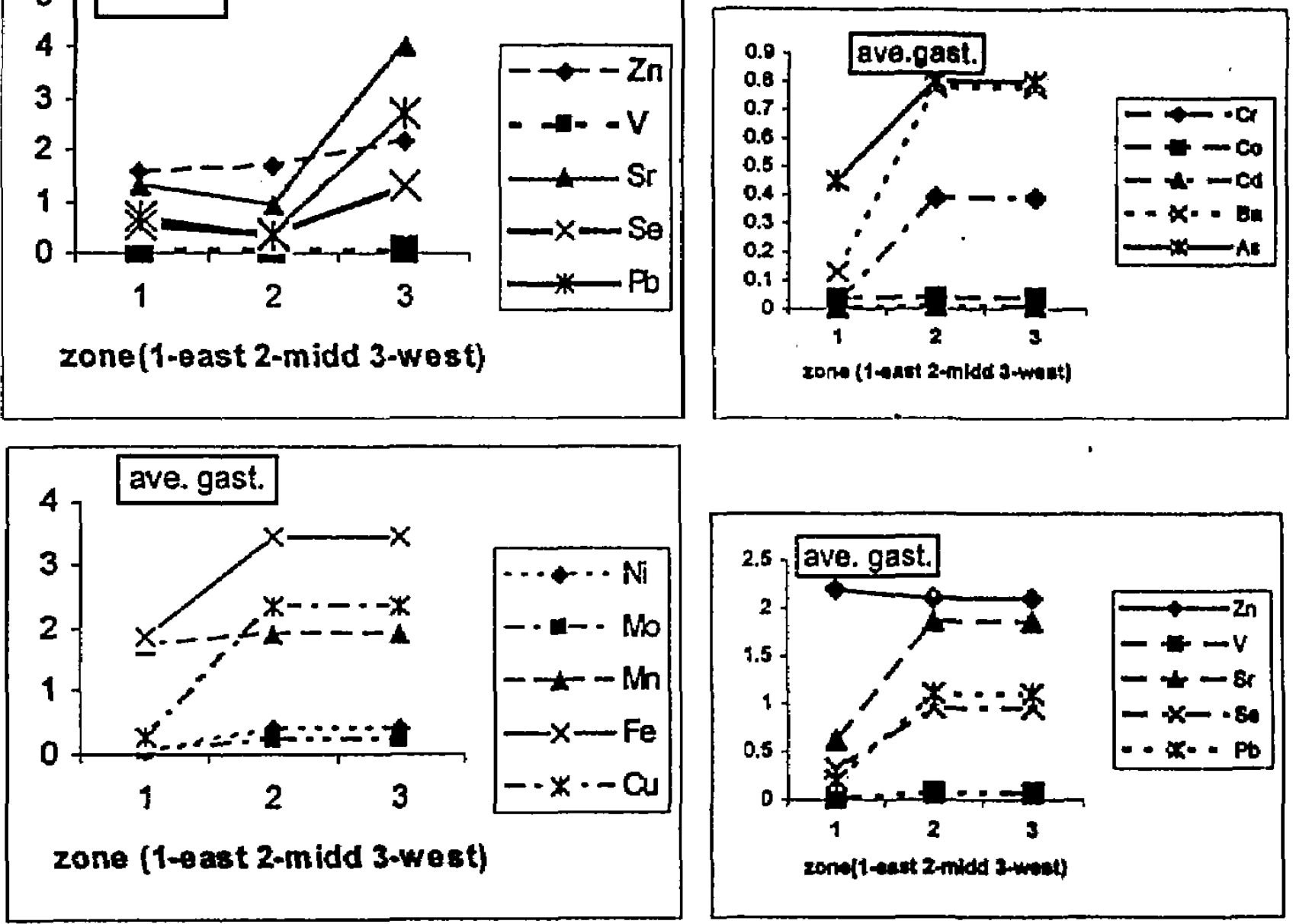